\title{
洪水流航空写真の画像解析
}

\section{Image Processing for Aerial Photographs of Flood Flow}

\author{
木下良作 \\ 宇民 正*，上野鉄男* \\ Ryousaku KINOSHITA \\ Tadashi UTAMI and Tetsuo UENO
}

\begin{abstract}
The aerial stereo photograph of a flood flow which is generally covered by patterns of foams and turbid flow was first analyzed by Kinoshita to obtain velocity distributions over the whole surface using parallax method.

In this paper, the automatically analyzing method of the same kind of photographs practical use was proposed. The cross-correlation method was used to obtain velocity vectors, and the method to correct the erroneous vectors and one for matching a pair of photographs were proposed.

Using the resultant distribution of velocity vectors the distributions of vorticity, divergence and streamlines were calculated and the structure of vortices occurring around the edge of the flood pain was examined.
\end{abstract}

\section{1. 概説}

洪水時航測写真による洪水流解析法は，既に20年以

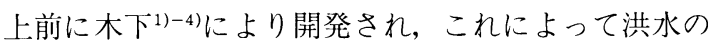
乱流特性や河川流の蛇行現象に関する新たな知見が得 られた。これを基礎に木下5)-12)は，河床砂州，河岸に 発生する大規模渦, 高水敷での土砂推積現象, 河道蛇 行特性などを解明し，さらに河道平面計画など河川工 学分野にも寄与してきた。

航空写真により直接に得られる河川流に関する情報 は乱流構造のある瞬間の水面における現象に関するも のである。木下秀,12)-14) は，洪水流解析によって見いだ された並列らせん流や河岸に発生する大規模渦などの 現象と類似の現象を実験室に再現し，その内部の構造

*京都大学防災研究所宇治川水理実験所

(京都市伏見区横大路下三栖東ノ口)

Disaster Prevention Research Institute, Kyoto University

「写真測量とリモートセンシング」Vol. 29,No.6, 1990
を検討するという手法をとった。これにより洪水流航 空写真測量の意義は一層高められた。

宇民・上野 ${ }^{15), 16)}$ は，木下の実験室における計測方法 を改良して流れの断層面における流況の 2 次元的な計 測法を開発した。すなわち, 流れの水平断層面をシー 卜状の光で照射してそこでの流況を僅かな時間差で 2 枚撮影し，1対の写真データの間に画像相関法を適用 してその断層面における流速べクトル分布を得た。

著者らは，上記の手法を洪水流航空写真の画像解析 に適用することにより, 洪水流航測の手法を, 従来の 立体困化機を用いる段階より一段と有用なものにする ことができると考えた。

すなわち，第 1 に，従来の方法では航空写真の主点 基線方向の流速成分のコンタ一眓と流速ベクトルとが 別々にかつ人の視覚を利用して眓化されていた。これ に対して，この方法では流速べクトルそのものが客観 的に数量化される。したがって解析処理のハードウ工 アーとソフトウエアーが完成すれば，数多くの航測写 真を自動的かつ正確に処理でき, 労力と時間が節約さ れるし, 解析に熟練を要しない。第 2 に, 前述の様に 従来の方法では航空写真の主点基線方向の流速成分の 
みが困化されるという制約があった。そのため，写真 撮影に際しても飛行経路の選択に制約があり, 操縦が 繁雑であったし，曲率の大きな弯曲部での流れの解析 が困難であった。一方，この方法では，解析は撮影機 の飛行方向に左右されないので, 撮影も比較的容易で あるし，弯曲部でも解析上の制約もない。第 3 に，数 量化された流速べクトルを用いて流速以外の各種水理 量 (流線, 発散, 渦度等) を計算し困化することがで きるので, 解析により得られる情報量も豊富である。

一方, 画像相関法を用いた写真画像の解析は, 空中 写真から地図の等高線を自動的に製作する方法とし て，既に1950年代の終り頃から開発されてきた。わが 国においては, 森ら ${ }^{17), 18), 19)}$ の先駆的な研究ならびに村 井ら ${ }^{20,21)}$ のニアアレイセンサーによるステレオ画 像を用いた研究などがある。これらは何れも，二つの 画像の立体視を自動化しょうとするものであり, 画像 のステレオマッチングの手法には面積相関法が用いら れている。

地困の自動図化に面積相関法を適用する際には, 相 関をとる面積 (相関空) の大きさの決定が難しいこと, また, 崖などの地形の傾斜の大きな所では隠蔽部分が 存在し,正しいマッチングができないこと,などといっ た問題点がある ${ }^{22)}$ 。森ら ${ }^{19)}$ および服部ら ${ }^{23), 24)}$ は, 画像の フィルタリング，ならびに，最初に粗にマッチングを 行い, 次第に細かいマッチングに移る段階的な手法 (course-to-fine 法) などを適用してこれらの問題に対 処した。

洪水流の解析においても, 僅かな時間差 ( 4 秒程度) をもって撮影された二枚の航空写真から相関法によっ て流速ベクトルを得るが，次のような特徵あるいは問 題点がある。

先ず第一に，解析の対象となる洪水流の表面は平滑 で殆ど水平に近く，また，洪水流は連続体であって地 形のような急激な変動がない。これは，地形解析の際 に問題となる画像の投影歪みが無く，鿵蔽部分も存在 しないことを意味している。したがってこの点では洪 水流解析は地形解析よりも容易である。

第二に，実用面に関しては，地形解析の場合は，そ の解析結果は沉用に供せられるために高度の厳密性が 要請されるが, 洪水流解析の場合は, 先ずその利用目 的が何であるかが重要であり，それに応じた精度の範 囲内で，ある場合には迅速性が要請されたり，ある場 合には解析手段や方法の簡便性が要請される。
第三に，洪水流解析のための洪水流写真撮影が容易 でない25)。洪水時には一般に天候は悪く,フライトに適 さない。さらに, 日本の場合洪水の生起時間は短いし, とりわけ洪水の表面のトレーサーとなるような気泡や 斑紋が現れる期間は限られている。洪水流解析では, 気象の変化を見てタイミングよくしかも鮮明な洪水流 の水面を撮影する高度の特殊技術が前提となる。写真 撮影に関しては, 洪水流撮影の場合は固定点から撮影 された写真でも解析可能であり，また，撮影時間間隔 の大小によって解析結果や精度が変ってくる。

第四に, 現実には完全かつ鮮明な写真画像を得るこ とは容易ではなく，(1)写真画像に雲影が入っている, (2)水面におけるトレーサーや斑紋が不十分, (3)日没の ために露光が不十分, (4)水面に太陽の反射が入ってい る, (5)橋などの構造物やその影が水面を横切っている, などと言った不具合を含む写真が得られることが多 い。これらの処理については特別の工夫が必要である。

本論文では，第三および第四の問題には触れず，実 用的な観点からの洪水流解析法について述べる。すな わち, 洪水流解析においても地形解析と同様な相関法 が用いられるが, 洪水流解析においてはそれに特有の 解析法が開発される必要がある。ここでは, 立体図化 機を使用しないことを前提としてこの方法について述 べると共に，この方法による解析でどのような情報が 得られるかについても考察する。

\section{2. 解析の方法}

面積相関法により流速ベクトルを求めた。この方法 による場合, 相関の悹の範囲内で平均化された流速べ クトルが得られることになる。したがって相関の空は なるべく小さい方がよいが，小さくし過ぎると誤べク トルを得る結果となる。そこで，流速べクトルの計算 は, 初めは粗く, 次には精密に, 2 段階に分けて行っ た。この方法は, 上記の問題に対処できる他に, 計算 時間を短縮できるという利点ももっている。

解析は立体図化機を使わないと言う趣旨で行われ， 以下のような手順で進められた。

\section{1 航空写真の数值化}

利根川下流における昭和 46 年洪水の航空写真フィル ム (No.972，No.973，時間差4.2秒)の密着焼付版 (困 $-1,22 \mathrm{~cm} \times 23 \mathrm{~cm})$ を京大大型計算機センターのドラ 


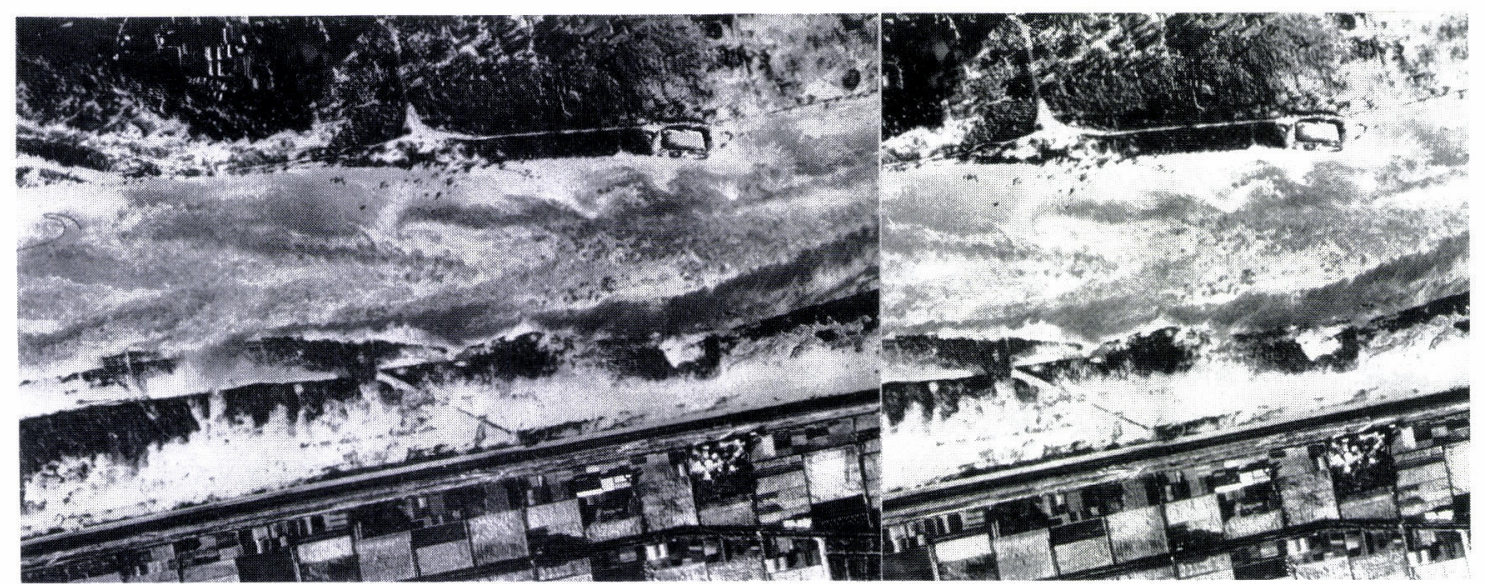

図一 1 解析した航空写真

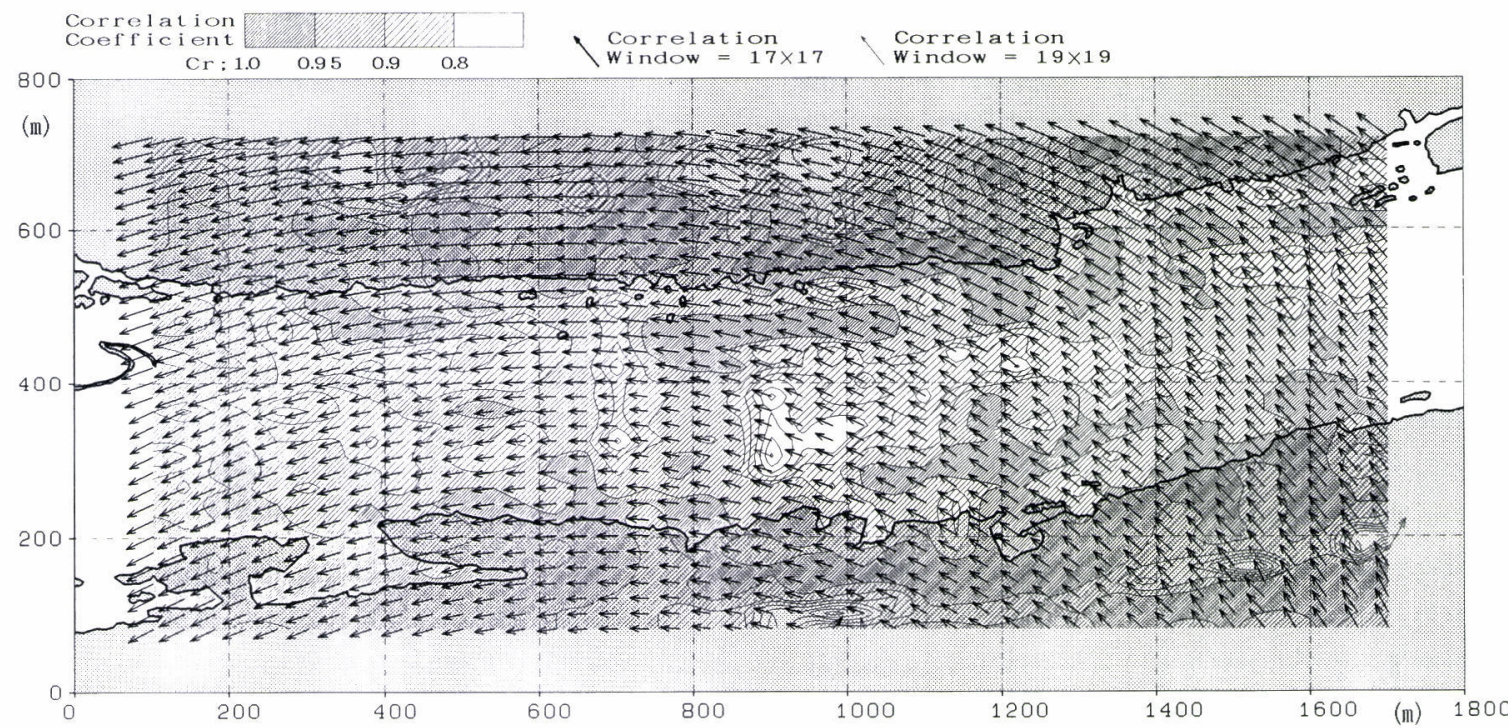

図一2 第 1 段階の相関解析によって得られた相関ベクトルの分布。太いベクトルは相

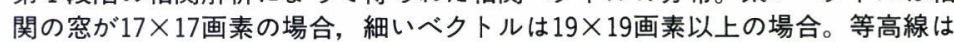
最大相関係数の分布を示す

ムスキャナ一を利用して, 50 ミクロンの分解能で 8 bit データとして数值化し, 磁気テープに入力した。数值 化の範囲は $18 \mathrm{~cm} \times 13 \mathrm{~cm}$ であり，したがってデー夕数 は3600×2600である。写真をドラムにセットする際に 生じる左写真と右写真の偏位や偏角は, 計算段階で処 理することとした。

数值化されたデータすなわち写真の濃淡の分布を計 算機に入力した。以下の解析における計算時間と計算 機の容量の制約のため, 隣りあう $2 \times 2$ 個の画素の濃 度の平均値を 1 画素の濃度に置き換えるという操作を
繰り返すことにより，各画素の間隔が100ミクロンの デー夕，200ミクロンのデー夕，ならびに400ミクロン のデータの三種のデータを作成した。なお, 座標系は, 200 ミクロンピッチデータの左下角を原点とする直交 座標系を用いた。

\section{2 相互相関解析の第 1 段階}

相互相関解析の第 1 段階では, 400 ミクロンピッチの 写真デー夕を用いて, 相関の空の大きさは, 17画素 $\times$ 17画素とした。得られたデータの内, 400 ミクロンピッ 


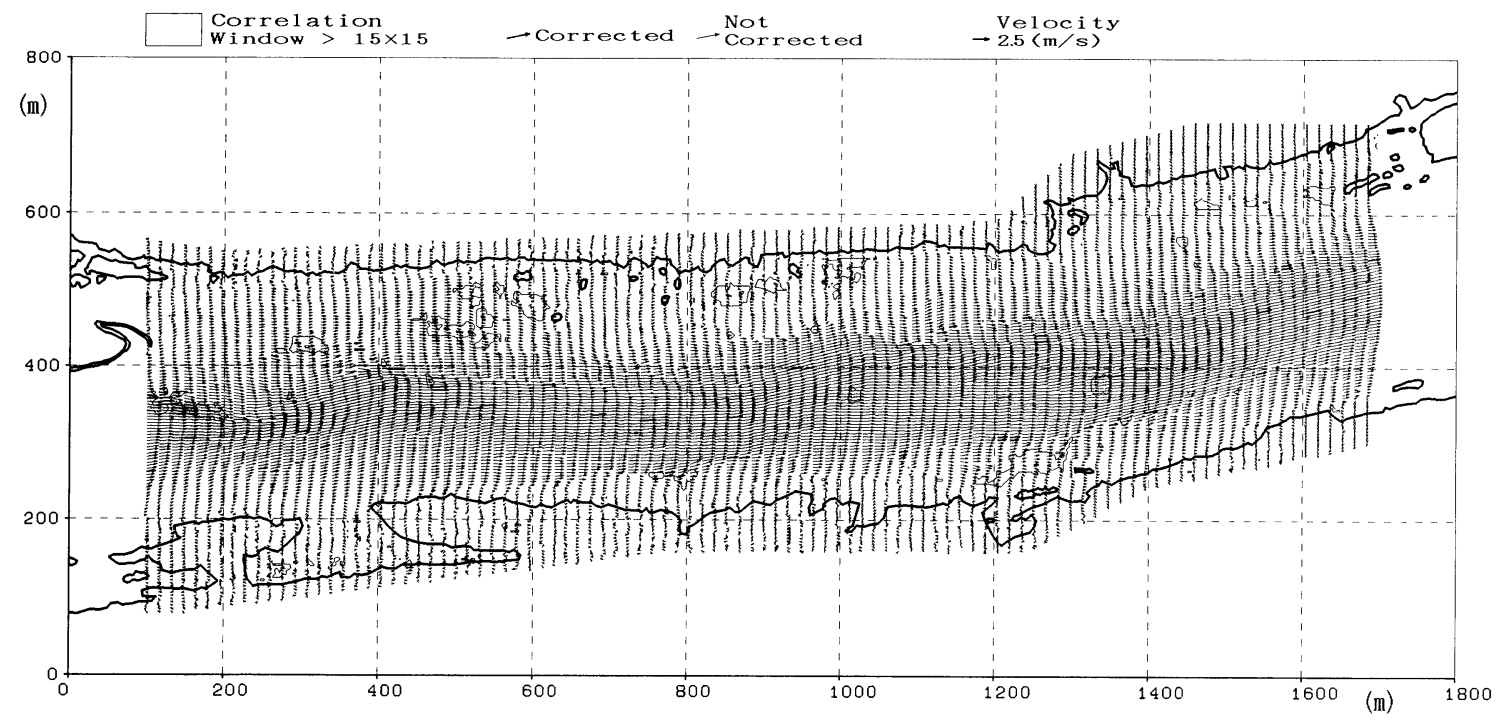

図一3 第 2 段階の相関解析によって最終的に得られた流速ベクトル。太いベクトルは 修正されたべクトル。陰影部分は相関の空が $15 \times 15$ 画素以上の場合, それ以外 は11×11画素の場合

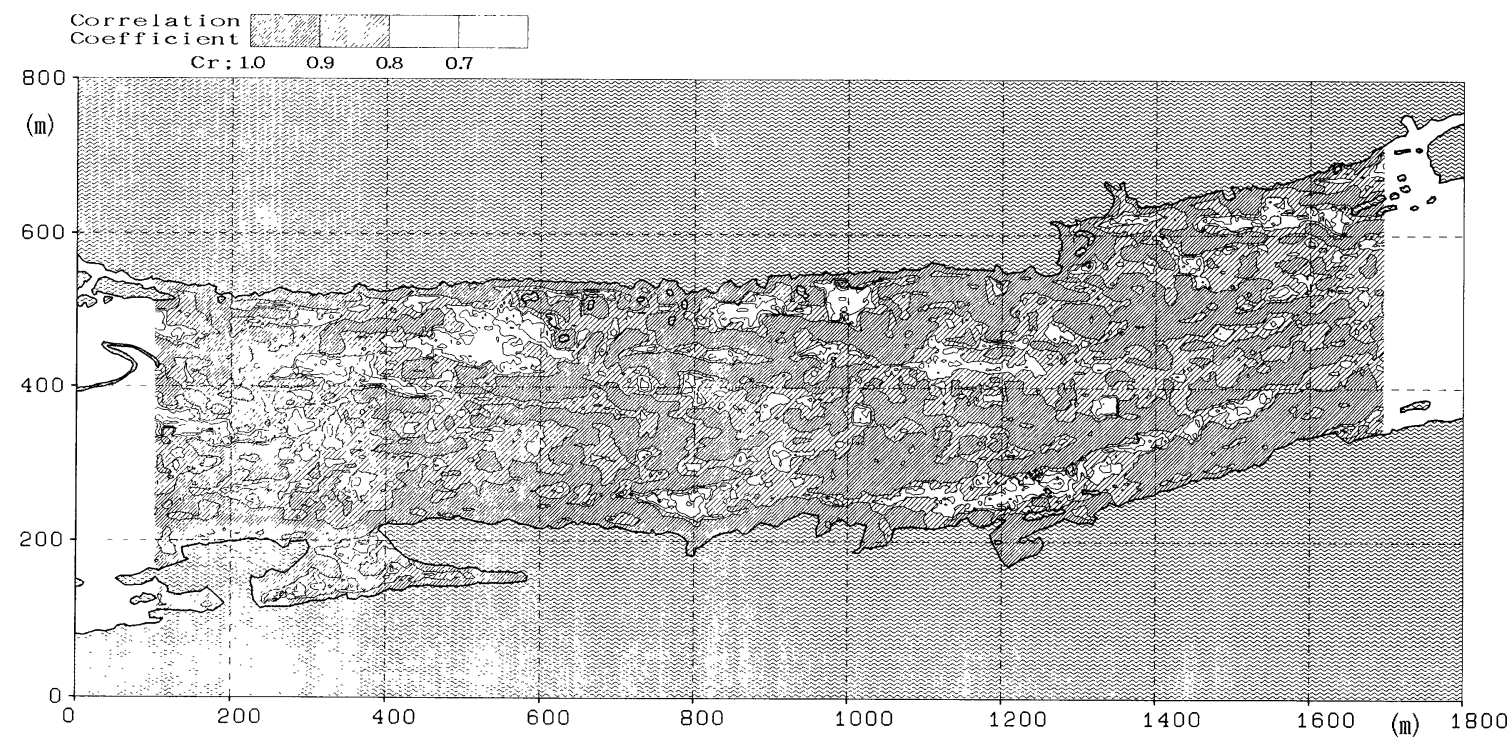

図一4＼cjkstart第 2 段階の相関解析における最大相関係数の分布

チデータの左右の写真の濃度分布のコンター図を描 き，両者を比較することによって，対応点の $\mathrm{x}$ 座標な らびにy 座標の最大偏差をそれぞれ見積った。その結 果，左写真の任意の点に対する右写真の対応点が $\mathrm{x}$ 方 向にはー30画素から 0 画素, y 方向には-10画素か
ら+10画素の範囲内に存在することがわかった。した がって，ここでは検索の範囲を上記の31画素 $\times 21$ 画素 の範囲とした。すなわち，右写真のこの範囲内で相関 係数が最大となる点を検索した。もしも得られた相関

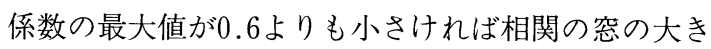


さを $\mathrm{x}$ 方向 $\mathrm{y}$ 万向に 2 づつ拡大して上記の相関計算を やり直した。

次いで, 相関係数最大の画素位置を中心とする 3 画 素 $\times 3$ 画素の各画素位置における相関係数の分布に最 小自乗法を用いて 2 次曲面を適合させ, 相互相関係数 が最大となる点の位置座標を計算した。以下において は，この様にして得られた左右写真の対応点同士を同 一の座標系の上で矢印で結んだものを相関べクトルと 呼ぶこととする。

洪水流は連続体であって, 地形のような急激な変化 がないことを考慮すると，相隣る相関べクトルは大き く異なることはない。したがって, 左写真のある点の 対応点の検索において相互相関係数の最大値に十分に 大きな值 (この場合は閾值を 0.9 とた) が得られた場 合には, その点に隣あっている左写真の点の対応点の 検索に際しては, その対応点の位置をある程度正確に 予測することができるので，上記の検索範囲31画素 $\times$ 21画素を11画素×11画素に縮小した。

対応点の検索は左写真の $\mathrm{x}$ 方向ならびに $\mathrm{y}$ 方向に 4 $\mathrm{mm}$ 毎に行われ, $\mathrm{x}$ 方向に41点, $\mathrm{y}$ 方向に 33 点, 合計 1353点について対応点が計算された。この計算で得ら れた結果を図一 2 に示す。本図で, 左右写真の対応点 同士を結ぶ相関べクトルが矢印で示されており, 洪水 流の水面以外の部分には院影（点）が施されている。 また, 各対応点の最大相関係数 $\mathrm{C}_{\mathrm{r}}$ がコンターで示され ているが，この值はかなり高いことがわかる。相関の 悹を17画素 $\times 17$ 画素よりも拡大して求められた相関べ クトルは細い実線で描かれているが，その数はごく僅 かである。

本図には，明らかに誤って算出されたと判断される 若干の相関べクトルが含まれているが，これらは水面 の領域の外にあって, 以後の解析には関係しないので それらを無視した。

\section{3 相互相関解析の第 2 段階}

相互相関解析の第 2 段階では, 200 ミクロンピッチの 写真デー夕を用いた。相関の空の大きさは, 11画素 $\times$ 11画素とし, 左写真の $\mathrm{x}$ 軸方向ならびに $\mathrm{y}$ 軸方向に 0.4 $\mathrm{mm}$ 毎に対応点を右写真から検索した。対応点の検索 に際しては, 第 1 段階の解析結果を内挿することに よって対応点の位置を予測し，その点の周りの 7 画 素× 7 画素を検索範囲とした。

\section{4 計算データの修正}

計算により得られた相関ベクトルの内には, 誤って 得られたものも若干含まれているので，それらを取り 除く必要がある。誤べクトルの除去のために, 洪水流 は連続体であり地形のような急激な変動がないことを 考慮して，以下の 2 種類の方法を試みた。

(1) 2 次元ヒストグラム法

得られた相関ベクトル場を小領域に分割し, 各小領 域内において相関ベクトルの $\mathrm{x}$ 方向成分 $\mathrm{u}$ と $\mathrm{y}$ 方向成 分 $\mathrm{v}$ に関する二次元ヒストグラムを作成し, モード值 からのふれが閯值を越える相関べクトルを除去した。

この方法による場合, 小領域が流れの強せん断層等 の流速の急変部を含む場合, 二次元ヒストグラムが二 山型となり, 正確に求められた相関べクトルまで廃棄 してしまうことがわかった。したがって, 結局この方 法は用いなかった。

(2) 3 次曲面適合法

相関ベクトル場内に小領域を設定し，そこにおける $\mathrm{u}$ 分布と $\mathrm{v}$ 分布に別々に最小自乗法を用いて 3 次曲面 を適合させた。各々の值と適合曲面との差が標準誤差 の $\mathrm{A}_{\mathrm{cr}}$ 倍を超える場合, その相関ベクトルを除去した。

ここでは小領域としてx方向に 12 相関ベクトル， $\mathrm{y}$ 方向に 9 相関ベクトルを含む領域を採用してそこにお ける $12 \times 9$ 個の相関ベクトルの内相関係数が 0.6 を超 えるものについて $\mathrm{u}$ 分布 $\mathrm{v}$ 分布のそれぞれについて 3 次曲面を適合させた。次いで, この小領域の中央部の $8 \times 5$ 個の相関べクトルについて上記 3 次曲面からの 差を検定した。この検定によって誤べクトルとされた ものについては，3次曲面によって与えられる值を もって相関ベクトルの成分とした。一対の写真から得 られた $1 つ の$ 相関ベクトル場について上記の検定を 3 度繰り返して行った。 $\mathrm{A}_{\mathrm{cr}}$ の值として本解析では 3.3 を 採用したがその根拠については次章に述べる。

\section{5 左右写真の位置合わせ}

洪水流航空写真撮影に際しては緊急に撮影体制に入 るので標定点を事前に設定しておくことは一般には困 難であること, 航空写真の解析結果の利用目的に応じ た精度の範囲で流速に関する情報が得られればよいこ と, 洪水流航空写真の解析には迅速性が要請されるこ と, 等を勘案して, 本解析においては左右写真の相互 標定は直接的には行わず，河川流の水際における相関 ベクトルが 0 になるように各相関べクトルを修正し 
た。洪水流の水面がほとんど水平に近いことを考慮す ると，このことは，左右写真の河川の水際線を一致さ せることを意味している。勿論, 評定点が確定してい る場合には，それを用いた標定を行えばよい。

相関べクトルは, $\mathrm{x}, \mathrm{y}$ 両方向に $0.4 \mathrm{~mm}$ 間隔で求め られているので, 水際線上における相関ベクトルは, 線型内挿計算により水際線に沿って $\mathrm{x}$ 方向に $0.4 \mathrm{~mm}$ 間隔で求められた。ただし, 河岸が流れの中に突出し ているような所や水当り箇所では, 水際線近くで流速 が大きくなるために水際線のマッチングが悪くなるの で，その様な場所における相関ベクトルは位置合わせ には使用しなかった。

この様にして得た水際線における相関べクトル分布 に 3 次曲面を最小自乗法を用いて適合させ，得られた 最適化相関べクトル分布を各相関ベクトルから差し引 くことによって河道内の流速べクトル分布を得た。

図一 3 は，この様にして得られた流速べクトルの分 布を示したもので，横断方向には解析で得られた速度 ベクトルのすべてが記入されており，流下方向には 4 つに一つの割合で記入されている。これら流速べクト ルのうち前項で述べた処理によって修正されたもの は，本図では太く描かれている。また，相関の空の 1 辺の画素数が11画素 $\times 11$ 画素を超えた所を陰影で示し ている。

本困には，水面領域のみならず，陸地部分の「流速 ベクトル」も描かれているが，これらは言うまでもな く土地の高低を表しており，水面領域における流速べ クトルに比べてずっと小さな值になっている（木 下 $^{2), 3)}$ 。

\section{3. 解析法の検討}

以上において, 洪水流航空写真の解析方法について その概要を述べた。本節では，この方法に含まれる問 題点のいくつかについて検討する。

\section{1 左右写真の間の偏角の検討}

図一 2 において，横方向に並んでいる相関べクトル の先端を平均的に連ねる直線が $\mathrm{x}$ 軸となす角度を計測 することにより, 左右写真の間の偏角 $\theta$ はほぼ 0.029 $\operatorname{rad}$ であることがわかる。この偏角 $\theta$ は写真撮影の際 の機体の旋回により，あるいは写真をドラムスキャ ナーにセットする際に生じたものと考えられる。 $\theta$ が
あまり大きいと, 左右の写真の相関の悹同士がその縁 辺近くでずれてくるおそれがある。相関の空の中心か ら $\mathrm{r}$ の距離にある点でのずれは $\mathrm{r} \theta$ であり, $\mathrm{r} \theta$ が 1 画 素の直径より十分小さければよい。

第 1 段階の相関解析の場合, 相関の悹の隅角部で $\mathrm{r}$ は最大值 $\sqrt{8^{2}+8^{2}} \times 0.4=4.5(\mathrm{~mm})$ をとク, $\mathrm{r} \theta=$ $0.13(\mathrm{~mm})$ で, $\mathrm{r} \theta$ は 1 画素の大きさ $0.4(\mathrm{~mm})$ よりも 十分小さいので問題は無いと考えられる。

第 2 段階の相関解析では, $\mathrm{r} の$ 最大值は $\sqrt{5^{2}+5^{2}} \times$ $0.2=1.4(\mathrm{~mm})$ であり, $\mathrm{r} \theta=0.04(\mathrm{~mm})$ で, 1 画素の 大きさ $0.2(\mathrm{~mm})$ よりも十分小さいのでさらに問題は 無い。

\section{2 相関の空の大きさに関する検討}

上記の相関解析において得られた各相関べクトルの 最大相関係数を図一 4 に示す。本図から最大相関係数 の值は全般的に非常に高いことがわかる。しかし，局

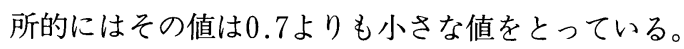

この様に最大相関係数が局所的に小さくなる主たる 原因としては，写真画像の濃淡分布がその付近で単調 なことが上げられる。四一 5 は，相関の空の大きさと 同じ11画素 $\times 11$ 画素の小領域毎に写真濃淡の標準偏差 を計算したものである。本図と図一 4 とを比較すると， 写真濃淡の標準偏差が 5 以下のときに最大相関係数が 非常に小さくなっていること，また，この様な標準偏 差の低下は剝離域や低速域などで生じていることがわ かる。

先の相関解析において, 得られた相関ベクトルの最 大相関係数が $0.6 よ り$ 小さい場合には相関の窓を拡大 して再度相関解析を行うという処理をした。写真の濃 淡の標準偏差の低い所ではその計算領域を拡大するこ とによって標準偏差が増大すること，ならびにその様 な場所では流速も小さく，したがって流速変動も小さ いことを考慮すると，上記の処理は，計算の精度をさ ほど低下させることなく，しかも䛊べクトルの算出を 避けるという点で適当であったと考えられる。

また, 図一 3 には, 相関の㝕の 1 辺の画素数が11画 素 $\times 11$ 画素を超えた所を院影で示している。これによ ると, 大部分のところで相関の㝕の大きさは11画素 $\times$ 11画素となっていること，また，それを超えたところ でも誤べクトルがとくに増加している様子は認められ ず，この点からも上記の方法の優位性が指摘される。

本解析では，相関の空の大きさを 11 画素 $\times 11$ 画素と 


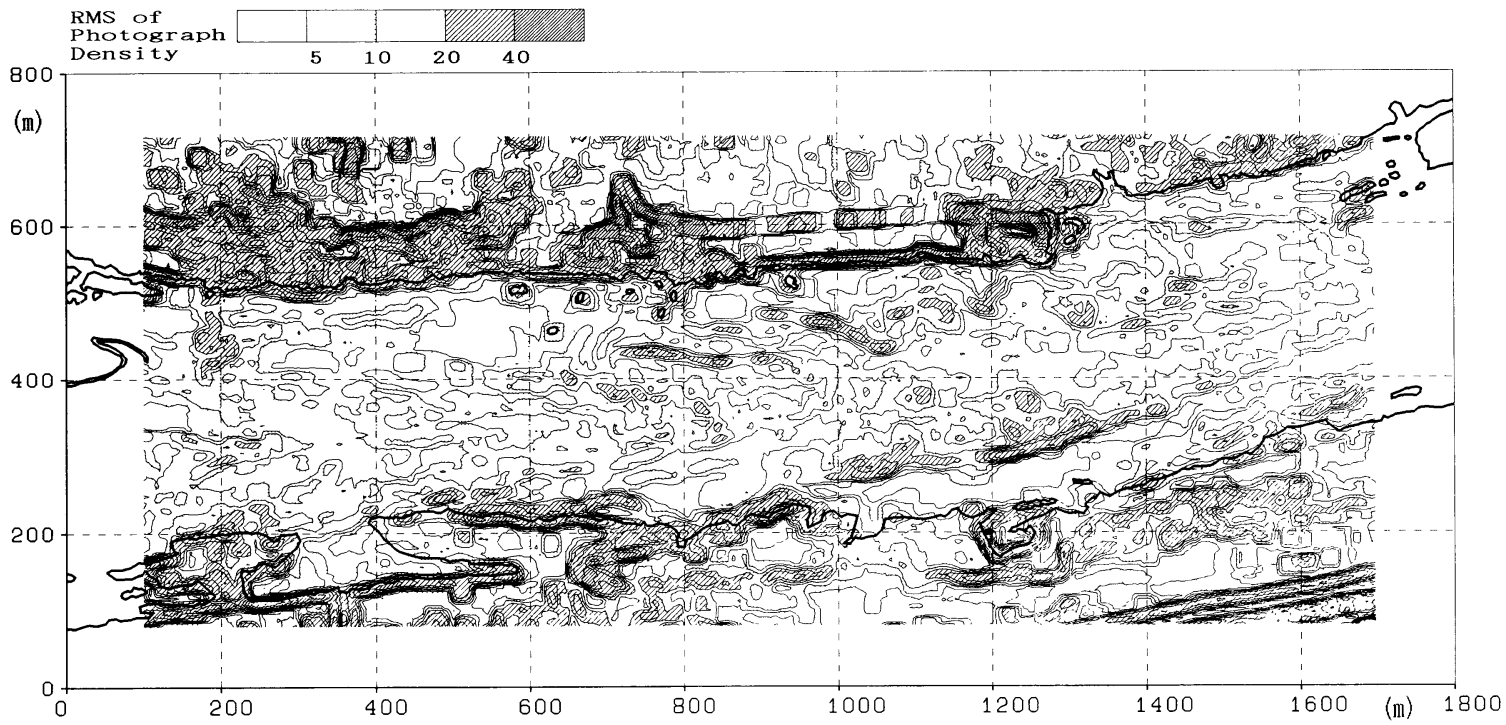

図一 5 写真の $11 \times 11$ 画素の範囲における濃度分布の標準偏差の分布

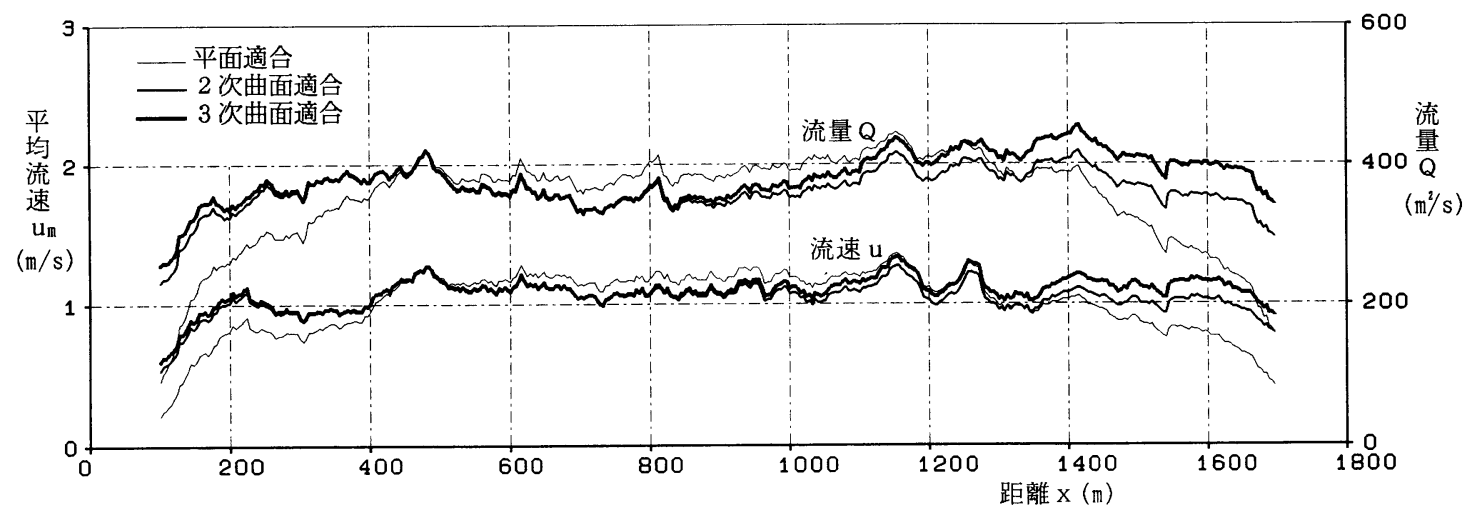

図一6 河川の各横断面における平均流速と流量の分布。3 本の曲線は, 左右写真の位 置合わせに平面適合を用いた場合，2 次曲面適合を用いた場合，ならびに 3 次 曲面適合を用いた場合に対応する

したが， 1 画素の大きさが $0.2 \mathrm{~mm}$ で写真縮尺が1／ 10,000であることを考虑すると，得られた流速べクト ルは $22 \mathrm{~m} \times 22 \mathrm{~m}$ の領域の平均的なものであることがわ かる。したがって本解析の結果は微細な乱流構造を示 すものとはなっておらず，10ないし20mより大きなス ケールの乱流構造を反映していると見なされる。

相関解析の第 3 段階として，1 画素の大きさが 0.1 $\mathrm{mm}$ のデータを用いて，相関の空をやはり11画素 $\times 11$ 画素として，水面領域内の狭い範囲について計算を試 みた。この場合は，流速べクトルは $11 \mathrm{~m} \times 11 \mathrm{~m}$ の領域
の平均的なものであるが，相関解析は十分正確な結果 をもたらすことが確認された。

ただ，上記のように，相関の空の大きさは写真の濃 度分布の影響をうけるし,また左右写真の時間間隔 4.2 秒の間の洪水の平均流下距離は $5 \mathrm{~m}$ であり，その間に 乱流構造も変形するので，相関の空の大きさをいたず らに小さくしても解析精度は向上せずに計算時間と デー夕の量を増大させるだけの結果となる。したがっ て，相関の空の大きさは写真解析の使用目的にあわせ て決めるべきであろう。 
写真解析の使用目的に応じて，左右写真の撮影時間 間隔, 写真数值化の分解能, 相関解析の相関空の大き さなどの值をいくらにとるべきかについては，今後の 課題としたい。また，本研究においては，紙面の制約 もあり,200ミクロンピッチのデータを用いた解析結果 について検討を加えることとし，50ミクロンピッチ デー夕および100ミクロンピッチデー夕を用いた解析 については触れないこととする。

\section{3 誤べクトルを除去する際の標準誤差の闘値の 検討}

2.4 で述べたように, 各相関べクトルの, 周辺小領域 における適合曲面からの偏差が標準誤差の $\mathrm{A}_{\mathrm{cr}}$ 倍を超 える場合，その相関ベクトルを誤べクトルとした。 $A_{c r}$ の值によって検出された誤べクトルの個数は表一 1 の 様である。

\section{表一1 3 次曲面適合法により検出された誤べクトル数}

\begin{tabular}{|c|c|c|c|c|}
\hline $\mathrm{A}_{c r}$ & 第 1 段階 & 第 2 段階 & 第 3 段階 & 合 \\
\hline 4.0 & 341 & 32 & 1 & 374 \\
\hline 3.5 & 729 & 85 & 14 & 828 \\
\hline 3.3 & 1011 & 166 & 23 & 1200 \\
\hline 3.0 & 1644 & 377 & 62 & 2083 \\
\hline
\end{tabular}

$\mathrm{A}_{\mathrm{cr}}$ の上記 4 種類の值について誤べクトルを検出し, その結果得られた相関べクトルを, 左右写真の位置合 わせにともなう修正を行った後, 図一 3 と同様の図化 をして視覚によって検討した結果, $\mathrm{A}_{\mathrm{cr}}=3.3$ のとき誤 ベクトルは殆ど完全に除去されていると認められた。 したがって，ここではその場合の結果を採用すること とした。

相関解析の第 2 段階では, 解析の対象とした写真流 域は $160 \mathrm{~mm} \times 80 \mathrm{~mm}$, 解析のピッチは $0.4 \mathrm{~mm}$ であるか ら，解析のメッシュ数は $400 \times 200=80,000$ である。し かし相関解析は, 水面部分およびその周辺領域の 44,357個のメッシュについてのみ行った。そのうち水 面領域にある相関べクトル数は 35,088 , さらにそのう ちの誤べクトルは993であった。したがって, 水面領域 では平均的に35個に 1 個の割合で相関べクトルが修正 されたことになる。

実際に，溃ベクトルを消去していない図と困一 3 と を比較すると，視覚的に判断して，若干の正しく求め られた速度ベクトルまで䛊ベクトルとして処理されて
いることがわかる。誤べクトルの検出法については今 後の検討が必要である。

\section{4 左右写真の位置合わせの方法の検討}

左右写真の位置合わせのために，水際線における相 関ベクトル分布に最小自乗法を適用し，それらに平面， 2 次曲面あるいは 3 次曲面を適合させた。適合させた 平面， 2 次曲面あるいは 3 次曲面に関して得られた適 合式は以下のようである。

平面；

$$
\begin{aligned}
& \mathrm{u}=-2.7200820+0.0071660 \mathrm{x}-0.0317618 \mathrm{y} \\
& \mathrm{v}=-1.9775540+0.0286408 \mathrm{x}+0.0035645 \mathrm{y}
\end{aligned}
$$

2 次曲面;

$$
\begin{aligned}
\mathrm{u}= & -3.0338890+0.0140790 \mathrm{x}-0.0295136 \mathrm{y} \\
& -0.0000656 \mathrm{x}^{2}-0.0000238 \mathrm{xy}+0.0000485 \mathrm{y}^{2} \\
\mathrm{v}= & -2.0392660+0.0272587 \mathrm{x}+0.0092391 \mathrm{y} \\
& -0.0000353 \mathrm{x}^{2}+0.0000159 \mathrm{xy}+0.0000348 \mathrm{y}^{2}
\end{aligned}
$$

3 次曲面；

$$
\begin{aligned}
\mathrm{u}= & -3.1811623+0.0132561 \mathrm{x}-0.0102967 \mathrm{y} \\
& -0.0000410 \mathrm{x}^{2}+0.0000651 \mathrm{xy}-0.0007067 \mathrm{y}^{2} \\
& +0.0000001 \mathrm{x}^{3}-0.0000004 \mathrm{x}^{2} \mathrm{y}-0.0000011 \\
& \mathrm{xy}^{2}+0.0000080 \mathrm{y}^{3} \\
\mathrm{v}= & -2.0801721+0.0264997 \mathrm{x}+0.0154451 \mathrm{y} \\
& +0.0000183 \mathrm{x}^{2}+0.0000013 \mathrm{xy}-0.0002628 \mathrm{y}^{2} \\
& +0.0000000 \mathrm{x}^{3}-0.0000000 \mathrm{x}^{2} \mathrm{y}-0.0000004 \\
& \mathrm{xy}^{2}+0.0000024 \mathrm{y}^{3}
\end{aligned}
$$

これによると， 2 次曲面と 3 次曲面に関しては，そ の適合式の定数項ならびに 1 次の項の係数はほぼ一致 しているが，平面の適合式のそれはかなり異なってい る。

以上のようにして得られた最適化相関べクトル分布 を各相関べクトルから差し引くことによって河道内の 流速べクトル分布を得た。その $\mathrm{x}$ 方向成分と $\mathrm{y}$ 方向成 分をあらためてそれぞれいおよび $\mathrm{v} て ゙$ 表すこととす る。

図一 5 で水際線のところで全般的に写真濃淡の標準 偏差が大きくなっており，図一 4 でも水際線のところ で最大相関係数の值は高くなっている。したがって左 右写真の位置合わせに用いられた相関べクトルは信頼 性の高いものであったことがわかる。

つぎに図一 6 は河川の各横断面における平均流速 $\mathrm{u}_{\mathrm{m}}$ と水深 $1 \mathrm{~m}$ 当りの通過流量 $\left(\mathrm{Q}\left(\mathrm{m}^{2} / \mathrm{s}\right)=\int \mathrm{u} d y\right)$ を 3 種の適合法に関して示している。これによると, い 
ずれの適合法によっても解析範囲の縁辺約 $100 \mathrm{~m}$ あた クで流量が極端に小さくなっている。解析の区間では 支川からの顕著な流入がないので，上記の流量はほぼ 一定であるべきである。このことを考慮すると， 3 種 の適合法の中では, 3 次曲面適合法の場合の適合性が 最も良いと言える。本解析で 3 次曲面適合法を用いた のはこの理由によっている。

なお，それ以外のところで，流量に約 1 割ほどの変 動が見られるが，これが実際現象を反映しているのか あるいは誤差のせいなのか，また誤差とすると，写真 の伸縮によるものなのかあるいは位置合わせの方法の 不備のせいかは明らかでない。

\section{4. 解析結果とその検討}

解析した写真（図一 1) は取手大橋の下流約 $4-6$ $\mathrm{km}$ の地点のものであるが, これを一見して, 両側の河 岸から流心に向かって流れを抱き込む腕のようなパ ターンが認められる。この様な流れパターンが, 流れ のどのような構造を反映しているものなのか，またそ の構造が河川工学的に（例之ば，流れの抵抗や土砂輸 送問題に）どのような意味をもっているのか興味がも たれる。

木下 ${ }^{26)}$ はここでの洪水の流下状況を検討した結果， ある特徵的なことを見いだした。すなわち，流量が約 $4,000 \mathrm{~m}^{3} / \mathrm{s}$ の時に粗度係数が異常に大きくなってお $\eta, そ の$ 時には低水路の両岸に大規模な渦が生じ，そ れらの干渉によって疎通が悪くなっていることを示し た。

本章では，以上に得た流速べクトル分布から流れの 構造や特性に関してどのような情報が得られるかにつ いて検討する。以下に揭げる図では, 解析領域のうち $\mathrm{x}=400 \mathrm{~m}$ から $1200 \mathrm{~m}$ の部分について拡大して示すこ ととする。

\section{1 流速, 流線, 渦度ならびに発散の分布特性}

図一 7 は流下方向流速成分 $\mathrm{u}(\mathrm{m} / \mathrm{s})$ の分布を示して いる。図において, 流速が $1 \mathrm{~m} / \mathrm{s}$ 以下の領域は河道の 高水敷に相当していると考之られる。高水敷の縁辺と 思われるところには強いせん断層があること, 水際近 くには逆流域を含めてかなり広く低速の領域が存在す ることがわかる。

図一8は流線を示している。本図から，流線の方向
と図一7 から得られる流心線の方向とは一致していな いことがわかる。また，水際近くでは渦運動が認めら れる。

図一 9 は渦度の鉛直方向成分の分布を示している。 図一 7 の等速度線が接近しているところで，渦度の絶 対值が大きくなっている。この様なせん断層は流下方 向に長く連なっており，興味あることに，その方向は 必ずしも流線とは一致していない。

図一10は発散の分布を示している。水面では発散の 正の值は流れの湧き上がりを，また負の值は沈み込み を意味する。

図中には，図一9に示されている渦度の正値の尾根 線（渦度の横断方向分布の局所的なピークの生じてい る位置を流下方向に連ねたもの）の位置を•印で, 同 様に負值の尾根線の位置を一印でそれぞれ示してい る。これらの印の対角線長は渦度の絶対值に比例して いる。興味あることに, 渦度の尾根線の周辺に発散の 絶対值の大きな領域が散在しており，しかもそれは涌 き上がりであったり，沈み込みであったりしている。

これらの四から, 高水敷の縁辺からは強いせん断層 が発達しており，そこには渦が連なっていることが予 想される。これらの渦を河岸渦と呼称することとする。 これら河岸渦の周辺には強い涌昇流と沈み込みとが混 在していることがわかる。

さらに図一 10 の $\mathrm{x}=850 \mathrm{~m}$ と $1100 \mathrm{~m}$ の間の低水路部 においては，発散の値はさほど大きくはないが，発散 の分布が網目状になっており, 網目の横断方向の間隔 は $16 \mathrm{~m}$ ないし $20 \mathrm{~m}$ となっている。

\section{2 河流の濁度の分布特性}

図一11に左写真の 400 ミクロンピッチデータの濃度 分布を示す。眓中の・印とロ印は先と同様に渦度の尾 根線の位置とその大きさを示している。本図から，強 い河岸渦の周辺では写真濃度すなわち河流の濁度が大 きくなっていることがわかる。これは，先述のように 河岸渦の周辺には強い湧昇流があり, それが河床近く の土砂濃度の高い流れを吹き上げ，それらが河岸渦に よってさらに拡散されるせいと考えられる。

先に度々指摘しているように, 流速分布, 渦度分布, 発散分布の特性は流線のパターンと異なっている。河 流の濁度分布特性も図一11から例外でないことが認め られる。 

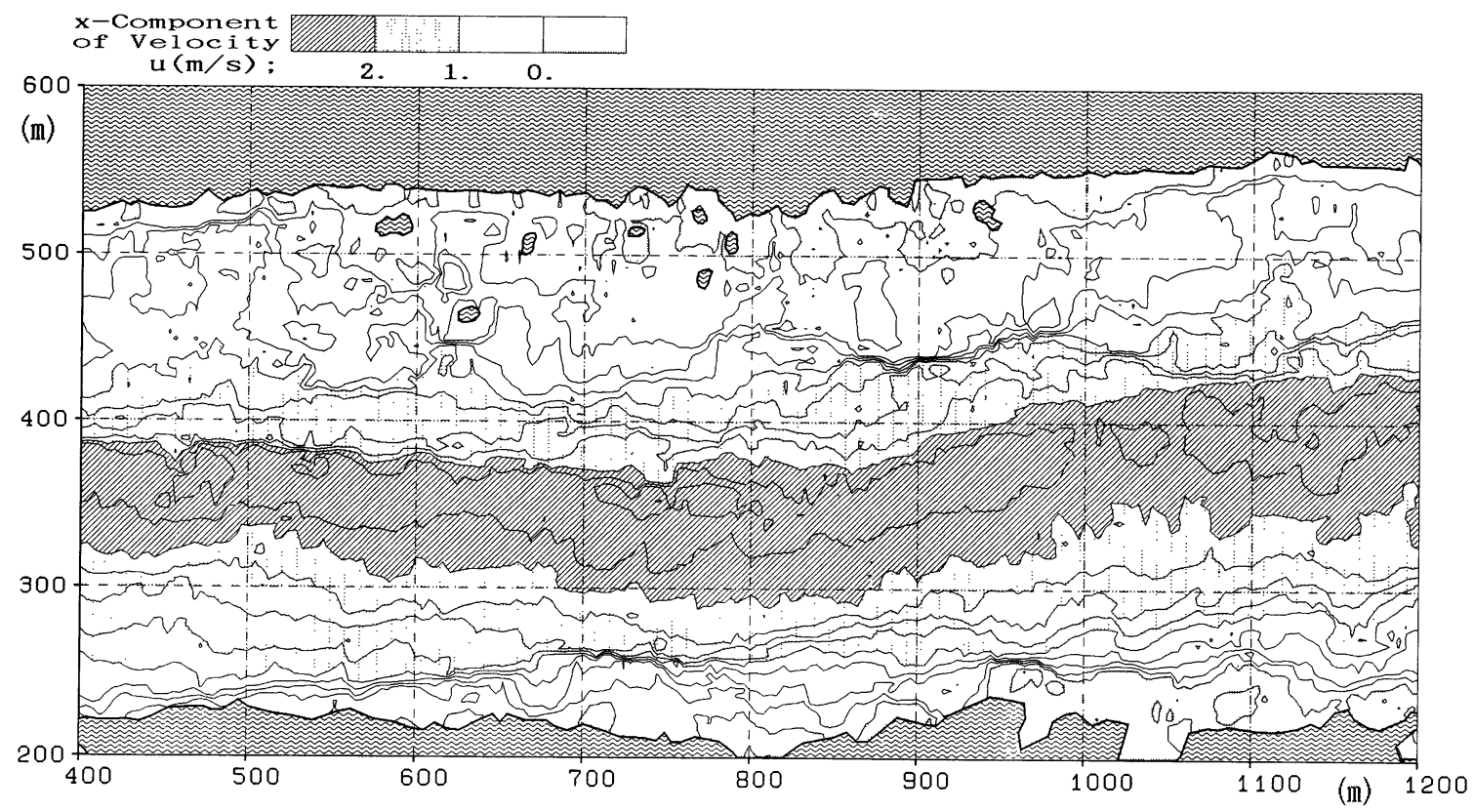

図一 $7 \mathrm{x}$ 方向流速成分 $\mathrm{u}$ の分布

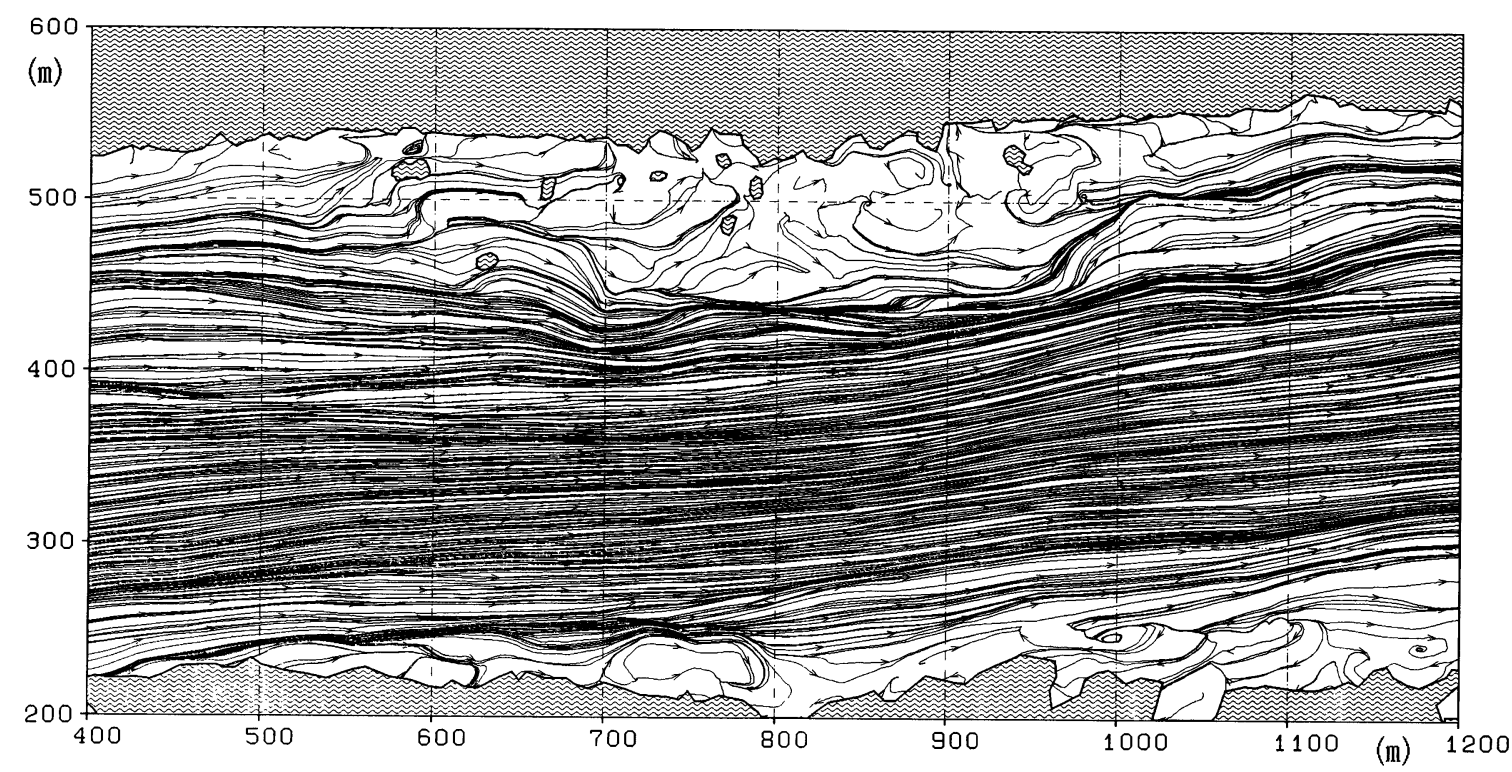

図一8 流線のパターン 


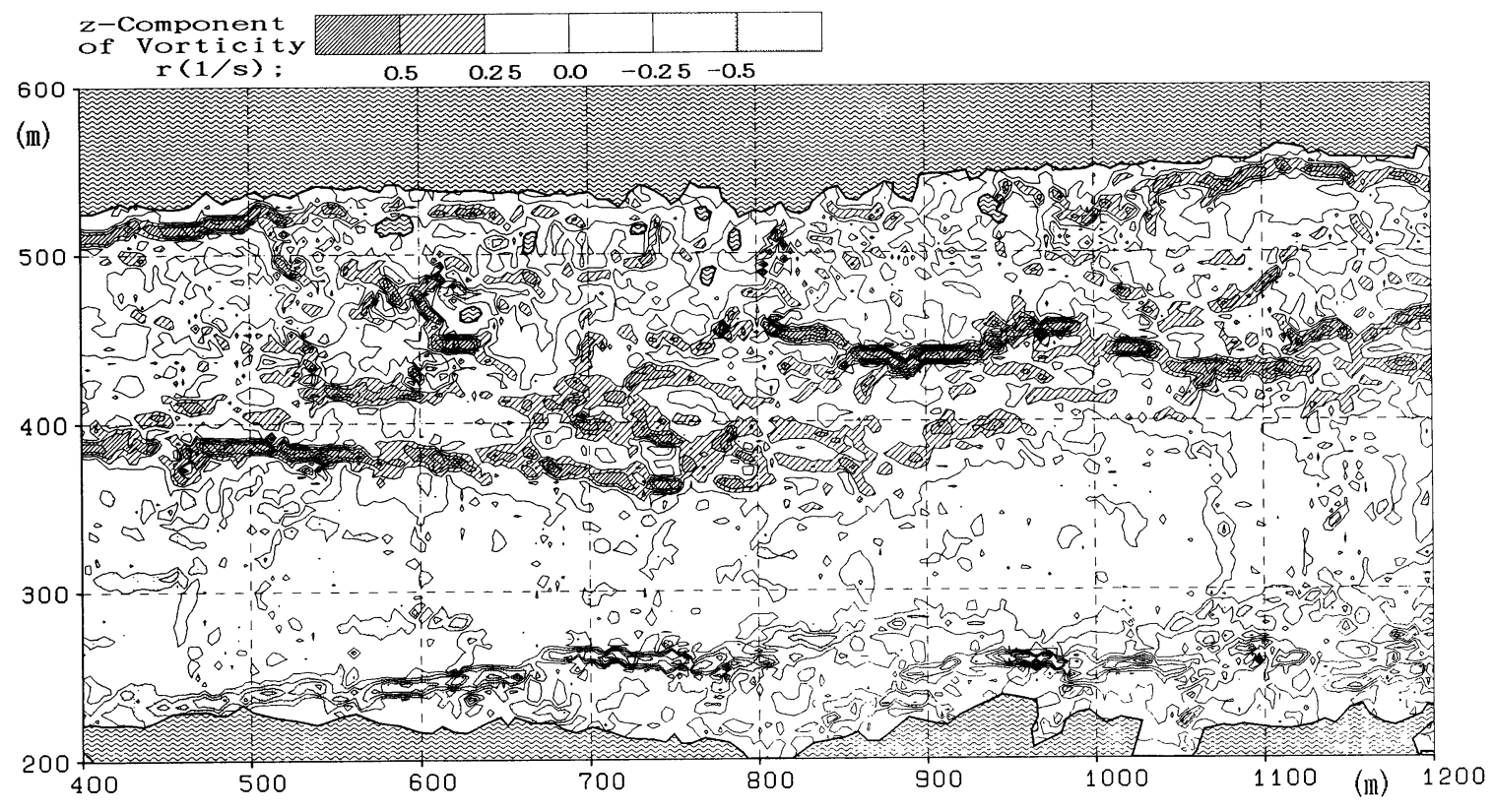

図一－9 鉛直方向渦度成分の分布

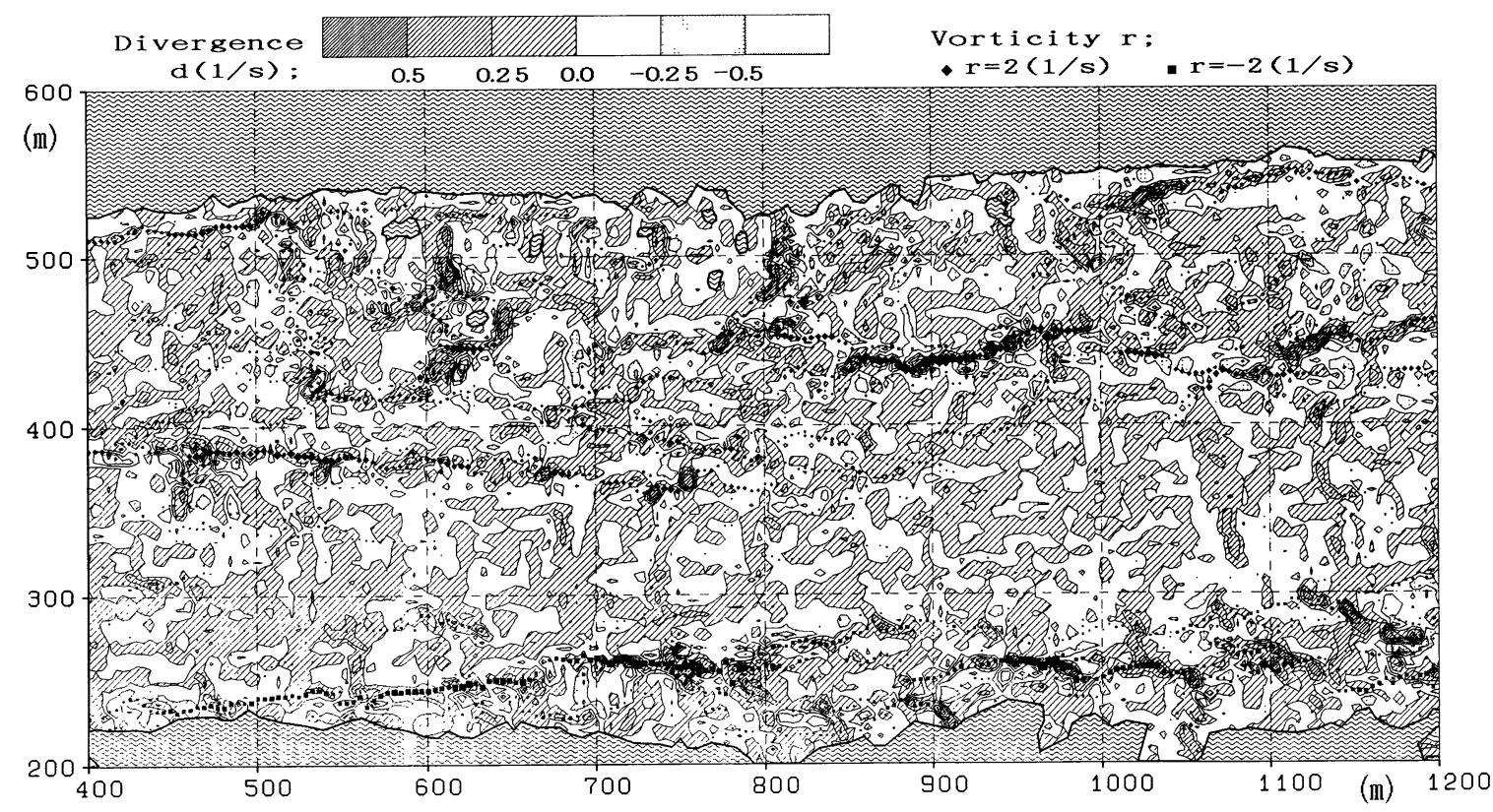

図一10 発散の分布(等高線)。・ならびにー印は, 渦度分布の尾根線ならびに谷線の位 置を示し，印の大きさは渦度の絶対值に比例する 


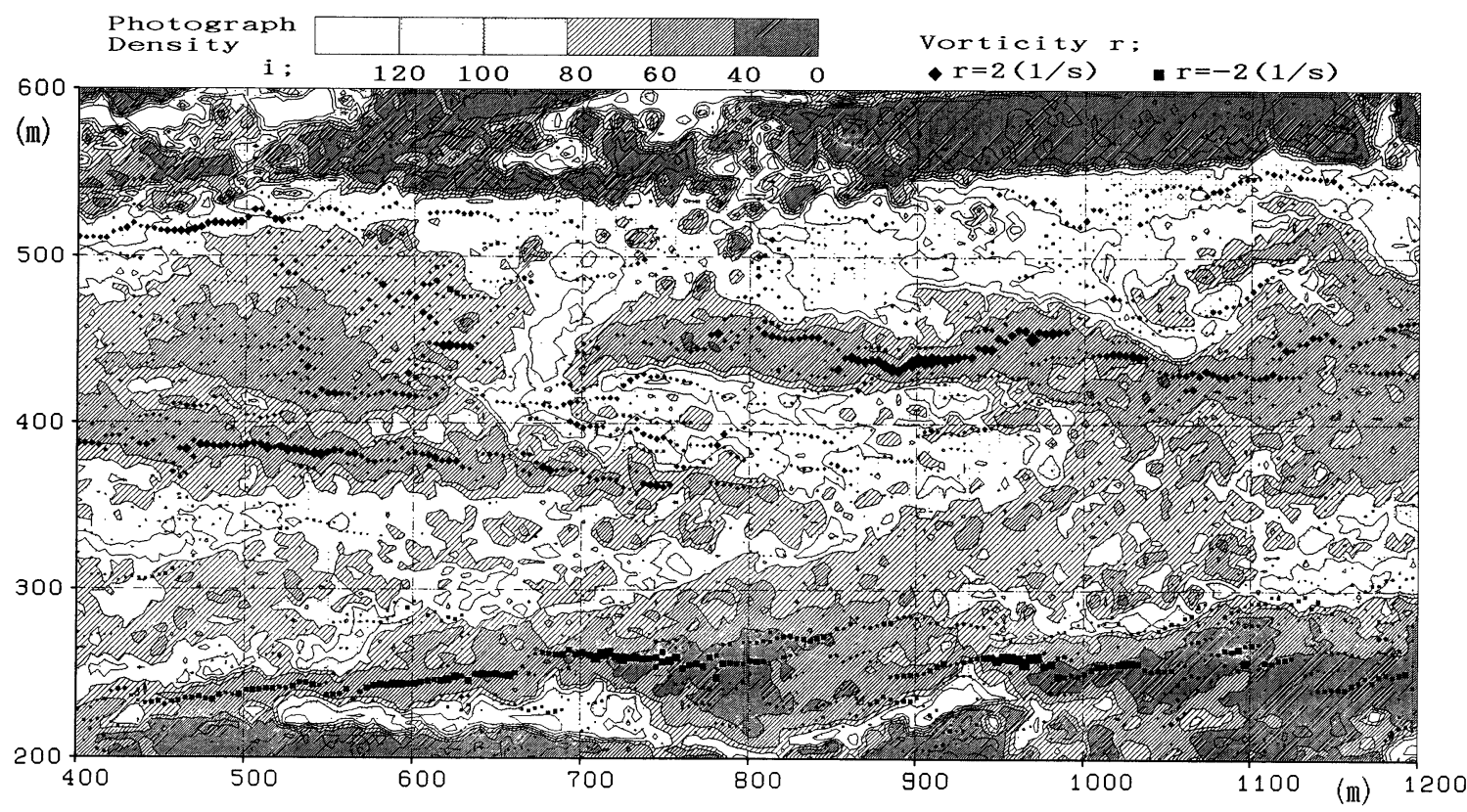

図一11 写真濃度の分布(等高線)。 なならびに・印は, 渦度分布の尾根線ならびに谷線 の位置を示し，印の大きさは渦度の絶対值に比例する

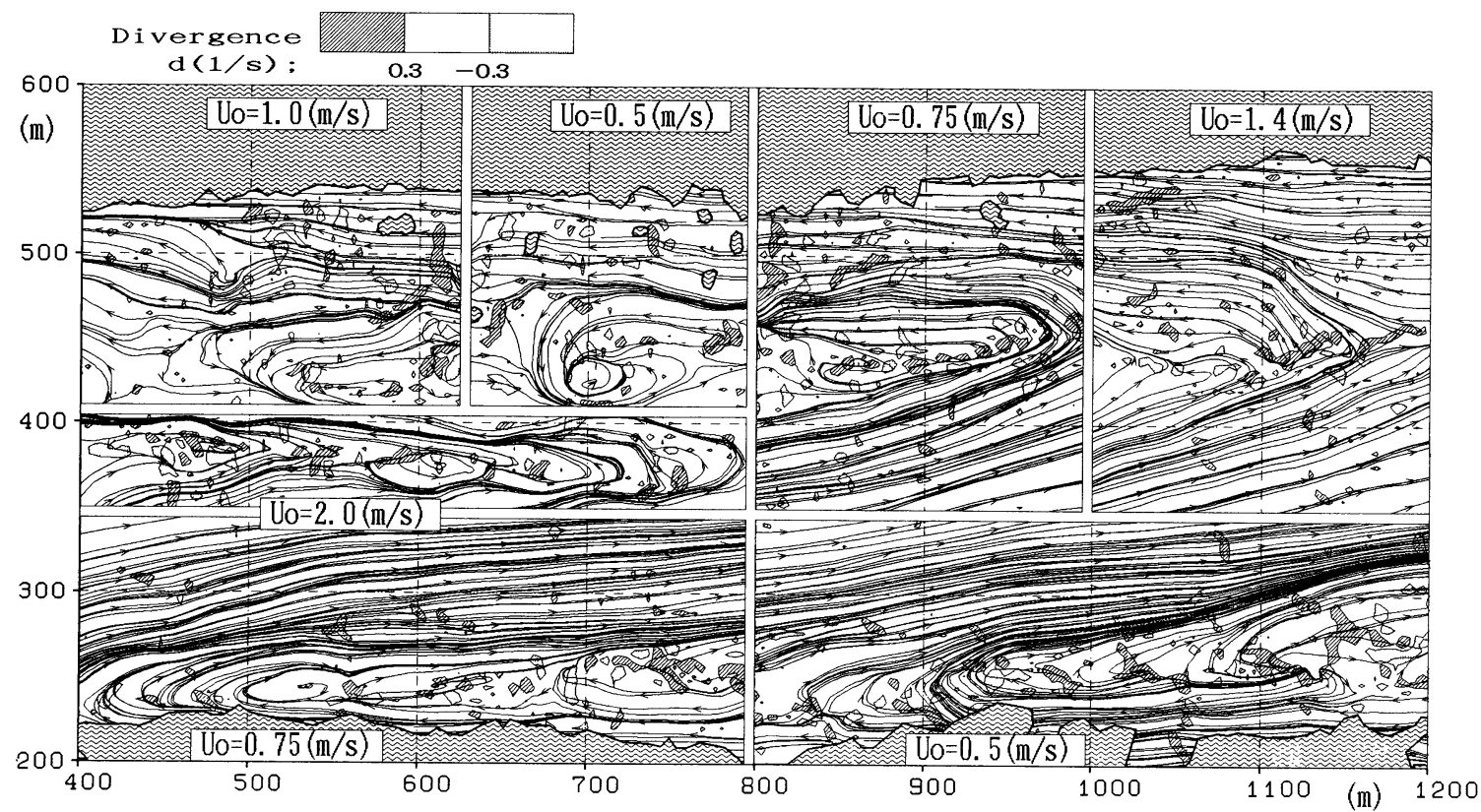

図一12 河岸渦をそれぞれの移流速度（Uo）に等しい移動系から見た場合の流線パター ンの合成図。図中の陰影は発散の絶対值が0.3を超える領域を示す 


\section{3 河岸渦の特性について}

图一 9 に示されている渦度分布において，渦度の絶 対值が特に大きな領域が流下方向に連なっており，そ れら一連の渦度分布が図一 1 に見られるような河岸渦 の一つを構成しているようである。しかも図一7 と図 - 9 とを比較すると, 一つの河岸渦の中では, 渦度の 尾根線の位置での流速はほぼ一定であることがわか る。

以上の事実から，河岸渦のそれぞれはその位置とス ケールに対応した独自の移流速度をもって流下してい ると考えられそうである。それぞれの河岸渦の形態に ついては，それぞれの移流速度で移動する系から見る と現象を理解しやすい。困一12は，流れの場を各河岸 渦が 1 区分を占めるように適当に領域区分し, 各領域 区分毎にその内部の流速分布からそこの河岸渦の移流 速度を差し引いたものを用いて流線を描き，それらを パッチワーク的に張り合わせたものである。用いられ た移流速度は, 渦度分布の尾根線あるいは谷線におけ る流速を図一7から読み取ったもので，各領域区分毎 に図中に示されている。図一12には，同時に，発散の 絶対値が 0.3 超える領域を陰影を施して表示した。

(1) 写真濃度との関連性

図一12と図一11とを比較すると，その全体的なパ ターンが驚くほどよく対応している。すなわち, 図一12 で流線の曲率の大きなあるいは流線が渦状に巻いてい る河岸渦の所では, 図一11において写真濃度が高く なっており，しかも，幅が広い河岸渦の周辺では写真 濃度の横断方向の広がりも大きくなっている。

さらに図一11において, $\mathrm{x}=910 \mathrm{~m} \sim 1200 \mathrm{~m}, \mathrm{y}=300 \mathrm{~m}$ $\sim 400 \mathrm{~m}$ の領域あるいは, $\mathrm{x}=1050 \mathrm{~m} \sim 1180 \mathrm{~m}, \mathrm{y}=470$ $\mathrm{m} \sim 520 \mathrm{~m}$ の領域で, 河岸渦はないが写真濃度が濃く なっていることが認められるが，図一12によれば，こ れはそれぞれの領域に近接する河岸渦によってもたら された濁度の高い流れがそこへ移流されたものと理解 される。

(2) 渦度分布との関連性

目一 12 と図一 9 に示されている渦度分布とを比較す ると, 渦度の大きなところと, 図一12の渦巻状の流線 パターンあるいは曲率の大きな流線パターンとは明確 に対応していること，ならびに一つの河岸渦は数個の 小規模の渦運動から構成されていること, しかも,こ れら小規模の渦運動の中心で渦度は特に大きくなって いることが認められる。
（3） 発散分布との関連性

発散が 0.3 を超える領域が図一 12 に斜線を施して示 されている。その位置は図一12では河岸渦を構成する 個々の小規模渦の境界に相当しており，そこでは流線 が発散している様子が明確に認められる。

(4) 河岸渦の構造

以上から明らかになった河岸渦の構造についてその 概要をまとめると以下のようである。すなわち， (1)一 つの河岸渦は, 流下方向に連なった強い渦度をもつい くつかの小規模渦運動によって構成されている。(2)河 岸渦はその発生位置とスケールに対応する移流速度で 移流されている。(3)隣りあう小規模渦運動の間には流 線の特異点（鞍型点あるいは結節点）が形成されてい る。(4)特異点を通過する一つの流線の周辺では, 強い 涌昇流がある。(5)涌昇流によって吹き上げられた河床 近傍の土砂濃度の高い流れは，小規模渦によって移流 拡散される。6この様な構造をもつため, 涌昇流は渦 度分布の尾根線或は谷線と斜交する細長い領域で発生 する。

河岸渦の移流速度, 発生位置, スケール, ならびに 強さについては今後の解明が必要である。

\section{5. 結 語}

洪水流航空写真の自動解析法について述べ，さらに 解析結果からどのような情報が得られるかについて検 討した。

最後に, 本研究の進展のため今後検討して行くべき 課題についてふれる。

(1)洪水流解析の使用目的に応じて，左右写真の撮影時 間間隔，写真数值化の分解能，相関解析の相関空の大 きさなどの最適值を明らかにすることが重要である。 (2)航空写真の解析のためには，その解析に耐える良質 の航空写真を撮影することが前提である。そのための 技術開発が重要である。

(3)本解析は汎用計算機でなされたが, 今後, 自動解析 のための専用のハードウエアーの開発が必要である。

(4)航空写真の解析から得られる情報は洪水表面での現 象に関するものであるから, その解析結果を, 数值シ ミュレーションや水理実験による結果と照合すること によってさらに突っ込んだ現象解明をすることが重要 である。

航空写真の数值化には, 京都大学大型計算機セン 
ターのドラムスキャナーを利用した。その使用にあた り寺嶋広次技官の援助を得た。末筆ながら記して謝意 を表する次第である。

\section{参 考 文 献}

1）木下良作：空中写真測量による洪水流の表面流速・流 向の測定, およびその分布状況と河床形状との関連性に ついて，第 8 回水理講演会， 1963，pp.65-66.

2 ）木下良作：航空写真による洪水流の解析, 写真測量, Vo1. 6, No.1, 1967, pp.1-17.

3 ）木下良作：洪水の構造をさぐる一航空写真からの新し い解析一, 科学朝日, 1967,7 , pp.22-28, pp.31-37.

4 ）木下良作：航空写真による洪水時の流況測定, 土木学 会水工学シリーズ, 1968.

5 ）木下良作: 河道平面計画試論, 土木学会水工学シリ一 ズ, A, 1972.

6 ）木下良作, 三輪式：砂レキ推の位置が安定化する流路 形状，新砂防，No.94，1974，pp.12-17.

7 ）木下良作：洪水流航測の河道計画への応用，写真測量 とリモートセンシング, Vo1. 14, No.2, 1975, pp.1-12.

8 ）木下良作：「写真測量法」による河川および模型水路の 流速測定, 流れの可視化, Vo1. 1, No.3, 1981, pp.36-43.

9 ）木下良作：航空写真に見られる洪水時の乱流現象，第 14回乱流シンポジウム, 1982, pp.39-54.

10）木下良作：昭和56年 8 月洪水による石狩川高水敷堆積 調査，石狩川開発建設部， 1983, pp.538-594.

11）木下良作：航空写真による洪水流解析の現状と今後の 課題, 土木学会論文集, No.345/II-1, 1984, pp.1-19.

12）木下良作：洪水時の沖積作用調査と適正複断面河道に 関する実験的研究, 沖積河川における洪水流の制御と治 水安全度の向上に関する研究, 文部省科学研究費自然災 害特別研究 (岸力代表) 報告書, 1988, pp.55-68.

13）木下良作：並列らせん流に関する実験的研究，石狩川 開発建設部, 1977 .

14）木下良作：洪水と流路形態の現地観測, 土木学会水工 学シリーズ, A, 1978.

15) Utami, T., R.F. Blackwelder and T.Ueno: Flow visualization with image processing of three-dimensional features of coherent structures in an open -channel flow, Intern. Seminar on Near-Wall Turbulence, 1988.

16）宇民正・上野鉄男：複断面蛇行流の可視化観測，京大防 災研究所年報，第32号，B-2，1989，pp.963-983.

17）森忠次・服部進・今井啓介・小川一郎：画像相関を使っ た空中写真からの等高線自動図化の一方法一一処理手法 と自動評定一，写真測量とリモートセンシング，Vol. 20, No.4, 1981, pp.4-13.

18）森忠次・服部進・内田修·田辺広志：画像相関を使った 空中写真からの等高線自動図化の一方法一偏位修正と 標高ファイルの作成一，写真測量とリモートセンシン グ, Vol.21, No.2, 1982, pp.4-14.

19）森忠次・服部進・内田修：分割画像ごとの相関法による 空中写真からの自動図化, 写真測量とリモートセンシン グ, Vol. 24, No.1, 1985, pp.13-22.

20）村井俊治・柴崎亮介：リニアアレイセンサによる数值 地形モデルの自動作成に関するシミュレーション，写真 測量とリモートセンシング, Vol. 23, No.3, 1984, pp. 13-21.

21）柴崎亮介・村井俊治：リニアアレイセンサによるトリ プレット ( 3 重ステレオ) 画像を用いたステレオマッチン グの精度, 安定性の向上に関するシミュレーション, 写真 測量とリモートセンシング, Vol. 26, No.2, 1987, pp. $4-10$.

22）服部進・森忠次：計算機によるステレオマッチング手 法と自動相関機の現況, 写真測量とリモートセンシング, Vol. 25, No.1, 1986, pp.17-26.

23）服部進・森忠次・内田修・藤原重雄; 空中写真のステレ オマッチングのための多段階相関法の改良 ( I ), 写真測 量とリモートセンシング, Vol. 25, No.1, 1986,pp.4-16.

24）服部進・森忠次・内田修・藤原重雄；空中写真のステレ オマッチングのための多段階相関法の改良 (II), 写真測 量とリモート七ンシング, Vol. 25, No.2, 1986, pp. 24-38.

25）木下良作：洪水流を航空写真に撮影する飛行の計画, 土木技術, Vol. 22, No.9, 1967, pp.49-57.

26）木下良作：利根川下流部の「渦形成問題」の検討, 利根 川下流部洪水流に関する検討業務解析報告書, 関東地方 建設局・アジア航測株式会社, 1980. 